Journal of

Molecular Microbiology

and Biotechnology
J Mol Microbiol Biotechnol 2010;18:1-13

DOI: $\underline{10.1159 / 000274307}$

Published online: January 6, 2010

\title{
Conditional Silencing of the Escherichia coli pykF Gene Results from Artificial Convergent Transcription Protected from Rho-Dependent Termination
}

\author{
Alexander A. Krylov Larisa G. Airich Evgeniya M. Kiseleva Natalia I. Minaeva
}

Irina V. Biryukova Sergey V. Mashko

Ajinomoto-Genetika Research Institute, Moscow, Russian Federation

\section{Key Words}

Elongation complex collisions · Gene silencing •

$R r n G$ anti-terminator $\cdot$ Transcription interference

\begin{abstract}
PykF is one of two pyruvate kinases in Escherichia coli K-12. $\lambda P_{L}$ was convergently integrated into the chromosome of the MG1655 strain, downstream of $p y k F$, face-to-face with its native promoter. In the presence of $\lambda c /$ ts 857 , efficient $p y k F$ ts-silencing was achieved when the $5^{\prime}$-terminus of the $P_{L^{-}}$ originated antisense RNA (asRNA), consisting of the rrnG-AT sequence, converted elongation complexes of RNA polymerase to a form resistant to Rho-dependent transcription termination. $p y k F$ silencing was detected by the following features: (a) impaired growth of the strain when $p y k A$ was also disrupted and when using ribose as a non-phosphotransferase system-transporting carbon source; (b) a pattern of reduced synthesis of the full-sized pykFmRNA, mediated by reverse transcription $P C R$, and (c) a significant decrease in PykF activity. The advantages of anti-terminated convergent transcription were clearly manifested in the strains where the rho_a-terminator was inserted specifically to interrupt asRNA synthesis. Most likely, the target gene was silenced by transcriptional interference due to collisions between converging RNA polymerases, although, strictly, the
\end{abstract}

role of cis-asRNA effects could not be excluded. While details of the mechanisms have yet to be determined, anti-terminated convergent transcription is a promising new technique for silencing other target genes.

Copyright $\odot 2010$ S. Karger AG, Basel

\section{Introduction}

The regulated redistribution of metabolic fluxes into branched pathways is extremely important for applied molecular microbiology and biotechnology when efficient biosynthesis of a desired product leads to growth retardation and decreased activity of the producing strain. Switching from the bacterial growth stage to bioconversion of substrates into desired products could be based on metabolically inducible transcription of recombinant pathway genes [Farmer and Liao, 2000; Imaizumi et al., 2007]. On the other hand, the silencing of some key genes could lead to a significant redistribution of the precursors into a desired metabolic branch as the result of a compensatory strategy [Kim et al., 2007], thus enabling the cell to maintain a stable state when exposed to various types of perturbations. At the very least, the deletions of some Escherichia coli genes involved in central metabolism [Mascarenhas et al., 1991] and/or global regulation

\section{KARGER}

Fax +4161306 1234 E-Mail karger@karger.ch www.karger.com

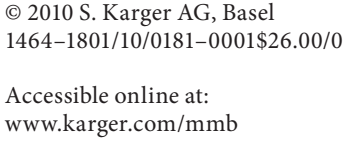

Prof. Sergey V. Mashko

Ajinomoto-Genetika Research Institute

1-st Dorozhny proezd, 1

RU-117545 Moscow (Russian Federation)

Tel. +7 495780 3378, ext. 511, Fax +7 495315 0640, E-Mail sergey_mashko@agri.ru 
[Tatarko and Romeo, 2001] of highly engineered strains lead to a greater increase in the performance of the strain than the more obvious genetic manipulations that amplify genes directly involved in a recombinant pathway.

Conditional silencing is a good alternative to chromosomal gene disruption, especially for genes that are essential for cell viability and active growth when knockout mutants cannot be successfully cultured [Nakashima et al., 2006]. Until recently, at least two general ${ }^{1}$ approaches appeared to be suitable for silencing genes in bacterial cells: first, the synthesis of antisense RNA (asRNA) [Ji et al., 2004; Kemmer and Neubauer, 2006; Kim and Cha, $2003]^{2}$ to downregulate its target gene by either blocking the binding of the ribosome or reducing the stability of the mRNA [Daugherty et al., 1989; Desai and Papoutsakis, 1999]; second, the interruption of mRNA formation of the target gene through transcriptional interference (TI) as a result of the presence of two, face-to-face aligned, convergent promoters [Adhya and Gottesman, 1982; Ward and Murray, 1979]. TI defined as 'the suppressive influence of one transcriptional process, directly and in cis, on a second transcriptional process', in general, can arise as a result of several different promoter arrangements [reviewed by Shearwin et al., 2005]. In case of convergent promoters, TI can interrupt mRNA synthesis through the following molecular mechanisms [Sneppen et al., 2005]: (a) 'promoter occlusion', in which passing E. coli RNA polymerase molecules (RNAPs) from convergent promoter block the access to the direct promoter [Adhya and Gottesman, 1982]; (b) 'sitting duck collision,' in which RNAP complexes that are waiting to fire at the promoter are removed by passing RNAPs [Callen et al., 2004], or (c) head-on 'elongation complex collision' (EC collision) between RNAPs as they try to transcribe from convergently aligned promoters, each thereby impeding the progress of the other [Ward and Murray, 1979].

Artificial asRNA genes, placed in trans in multi-copynumber plasmids [Kemmer and Neubauer, 2006; Srivastava et al., 2000], are usually constructed for bacterial

\footnotetext{
1 In some cases, an effect that looks like gene silencing may be achieved by a controllable degradation of protein product [see, for instance, McGinness et al., 2006], but this approach is based on protein-specific modifications including possible infringement of enzymatic activity; therefore, this approach cannot be considered as a general solution.

${ }_{2}$ Gene-specific silencing induced by the synthesis of artificial parallel complementary RNA (pRNA) has been described as well [Liu et al., 2009; Tchurikov et al., 2000]. But the mechanisms of the parallel RNA-RNA duplex formation in vivo and its influence on mRNA expression are not clear.
}

gene silencing. The efficacy of silencing depends appreciably on the stability of the asRNA and the features of its hybridization with mRNA [Engdahl et al., 1997, 2001]. For these reasons, improvements in silencing induced by artificial asRNAs in E. coli have been based on the systematic alteration of parameters and the targeting of multiple reporter and essential genes [Cheng et al., 2009; Nakashima et al., 2006]. Nevertheless, even in the best manmade constructions of asRNA genes located in trans, the expression level of the silenced target seldom decreases to lower than $30-40 \%$ of the wild type [Kemmer and Neubauer, 2006].

Gene silencing based on transcription from a promoter inserted convergently downstream of the target gene has been convincingly demonstrated [Elledge and Davis, 1989; Ward and Murray, 1979]. Nevertheless, the practical application of the TI-based approach has been limited; even when the corresponding man-made constructs were used, the formation of cis-encoded asRNA was considered to be the main factor in the observed gene silencing [O'Connor and Timmis, 1987].

In E. coli, two genes, $p y k F$ and $p y k A$, have been found to encode pyruvate (PYR) kinases [Ponce et al., 1995]. When glucose is the sole carbon source, both isoenzymes have an active role in PYR biosynthesis, but the specific activity of PykF is 15 -fold higher than that of PykA. Inactivation of only one of the pyk genes under phosphotransferase system-inducing $\left(\mathrm{PTS}^{+}\right)$conditions leads to a slight decrease in the bacterial growth rate on glucose, but disruption of both PYR kinase genes results in a more significant decrease [Ponce et al., 1995] and altered flux ratios for reactions connecting the phosphoenol-pyruvate (PEP) and PYR pools [Gosset et al., 1996; Ponce et al., 1998; Sauer et al., 1999; Siddiquee et al., 2004]. Ponce et al. [1995] showed that when ribose, a nonPTS sugar, was used as the sole carbon source, single $p y k$ mutants were capable of growth; however, the strain bearing the double $p y k A-p y k F$ mutation was unable to grow on ribose because it lacked the ability to produce PYR (fig. 1).

The $\lambda \mathrm{P}_{\mathrm{L}} / \mathrm{O}_{\mathrm{L}}$ regulatory region $\left(\mathrm{P}_{\mathrm{L}}\right)$ has one of the strongest promoters recognized by E. coli $\sigma^{70}$-RNAP [Deuschle et al., 1986; Liang et al., 1999], is governed by the $\lambda$ CIts857 repressor in a temperature-dependent fashion [Ptashne, 1992], and is stimulated by integration host factor (IHF) [Giladi et al., 1992; 1996]. The nutL sequence essential for N-dependent anti-termination of transcription of the $\lambda$ genes [Greenblatt et al., 1993; Ptashne, 1992] is located immediately downstream of $\mathrm{P}_{\mathrm{L}}$ in the native phage DNA. 
To construct strains with $p y k F$ genes that were conditionally silenced due to the influence of TI between converging RNAPs on their expression, we integrated $P_{L^{-}}$ carrier DNA fragments convergently into the chromosome of an E. coli MG1655-based strain, downstream of $p y k F$ and face-to-face with its native promoter. In the presence of $\lambda$ cIts857, more efficient $p y k F$ conditional (temperature-driven) silencing was achieved when the $r r n G$ anti-termination sequence (termed $r r n G-A T$ in Albrechtsen et al., [1991]) was placed downstream of $P_{L}$ instead of the nutL sequence possessed by the native, $\left(\mathrm{P}_{\mathrm{L}}-n u t L\right)$ carrier, $\lambda$ DNA fragment. The corresponding modification of the $5^{\prime}$-terminal part of $\mathrm{P}_{\mathrm{L}}$-originated nascent transcripts containing $r r n G-A T$ could convert RNAP elongation complexes into forms that were resistant to Rho-dependent termination [Albrechtsen et al., 1990; Condon et al., 1995; Squires et al., 1993]. We anticipate that designs similar to the synthetic, anti-terminated, convergent transcription process described in this work could conditionally silence different target genes that are relevant to applied molecular microbiology and biotechnology.

\section{Results}

\section{Structure of the pykF Gene in the Chromosomes}

\section{Differed between Constructed Strains}

E. coli mutants were constructed with alterations in the $p y k$ genes and with a disruption in the edd-eda operon encoding the PYR kinases and enzymes of the Entner-Doudoroff pathway, correspondingly. $\lambda$ Red-driven insertion of the set of DNA fragments carrying $\mathrm{P}_{\mathrm{L}}$ as the convergent promoter was provided downstream of the putative Rho-independent terminator [Kingsford et al., 2007] of $p y k F$, according to the procedure described by Datsenko and Wanner [2000] (fig. 2). For chromosomal rearrangements, the excisable marker $\lambda a t t L-\mathrm{Cm}^{\mathrm{R}}-\lambda a t t R$ was used for selective DNA integration followed by curing the marker with $\lambda \mathrm{Xis} / \mathrm{Int}$ recombinase, as described earlier [Katashkina et al., 2005]. Several of the strains possessed the $r r n G-A T$ sequence instead of the native nut $L$ sequence downstream of $\mathrm{P}_{\mathrm{L}}$ (fig. 2), which may protect the $\mathrm{P}_{\mathrm{L}}$-originated $p y k F$ asRNA from Rho-dependent transcription termination. Strains with the convergently facing Rho-dependent terminator rho_a [Albrechtsen et al., 1990] downstream of $p y k F$ (fig. 2) were also constructed. In the latter strains, $\mathrm{P}_{\mathrm{L}}$-driven transcription could be terminated or anti-terminated at rho_a, depending on the presence of $r r n G-A T$ in the nascent tran-

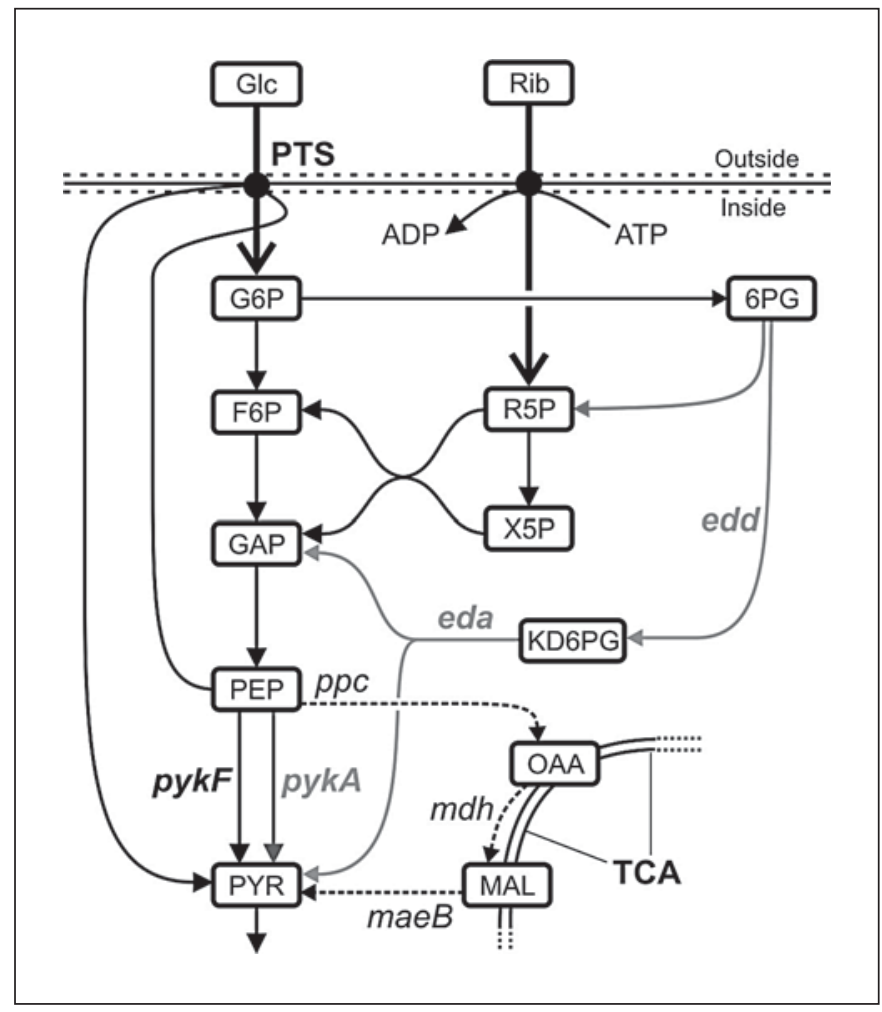

Fig. 1. Simplified scheme of PYR biosynthesis in E. coli using different carbon sources. Only genes that are mentioned in the text are indicated in the corresponding metabolic pathways. $6 \mathrm{PG}=$ Gluconate-6-phosphate; F6P = fructose- 6 -phosphate; G6P = glucose- 6 -phosphate; GAP = glyceraldehyde-3-phosphate; Glc = glucose; $\mathrm{KD} 6 \mathrm{PG}=2$-keto-3-deoxy-gluconate- 6 -phosphate; $\mathrm{MAL}=$ malate; $\mathrm{OAA}=$ oxaloacetate; $\mathrm{R} 5 \mathrm{P}=$ ribose-5 - phosphate; $\mathrm{Rib}=$ ribose; TCA = tricarboxylic acid cycle; X5P = xylulose-5-phosphate.

script. The structures of the resulting insertions were confirmed by sequencing. The constructed strains are listed in table 1.

\section{Effect of the Mutations on pykF Expression}

The growth of the strains was tested on solid media supplemented with glucose or ribose as the sole carbon source. The strains that were modified only by 'simple' gene/operon deletions manifested growth features that accorded with their predicted ability [Ponce et al., 1995] to produce PYR in different branches of metabolism by PTS, PYR kinases, and/or in the Entner-Doudoroff pathway (fig. 1). A very poor, but detectable growth on ribose of the AK000 strain, with $p y k A F$ and edd-eda genes deleted, was considered as '-' in table 1 , and could likely be explained by the possible formation of some amount of PYR due to 


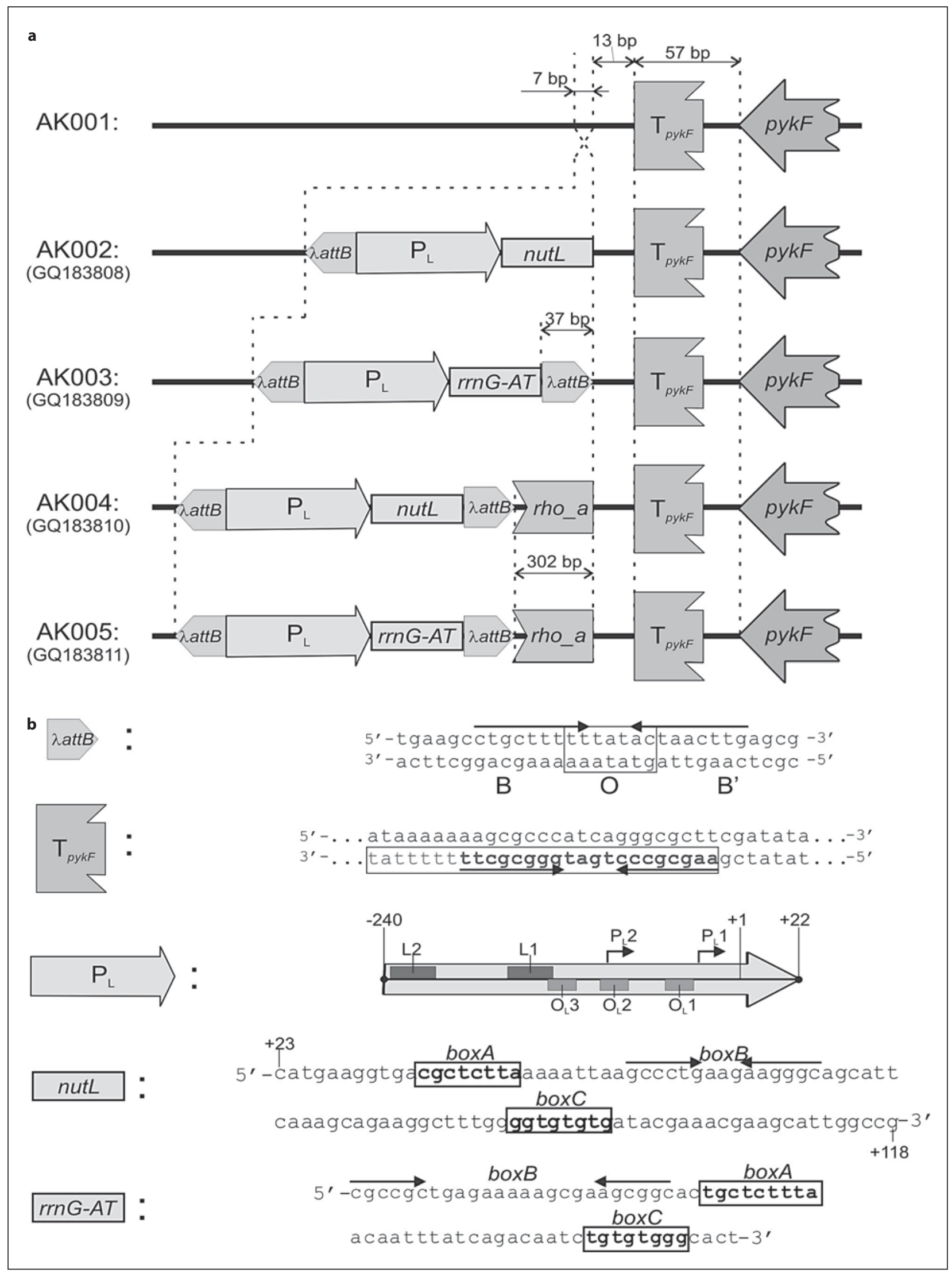


an activity of malic enzyme (product of maeB gene) [Siddiquee et al., 2004] in the PEP carboxylase (Ppc) - malate dehydrogenase (Mdh) - malic enzyme (Mae) shunt (fig. 1). $\mathrm{AK} 002$ and AK003, the $\Delta(p y k A$, edd-eda)-based strains carrying $\mathrm{P}_{\mathrm{L}}$ as the convergent element to the $p y k F$ promoter, demonstrated the $\mathrm{Pyk}^{-}$phenotype. Their growth on glucose was clearly poorer than the isogenic AK001 strain with the wild-type $p y k F$ gene ( $p y k F-\mathrm{wt}$ ), and they were almost unable to grow on ribose, similar to the $\triangle p y k A F$ strain, AK000. The AK002 and AK003 strains grown on glucose showed a residual PYR kinase activity that did not exceed 5\% of the level in AK001 (table 1).

Thus, the $\mathrm{P}_{\mathrm{L}}$-carrier strains AK002 and AK003 did not differ from each other with respect to the $p y k F$-silenced

Table 1. Description of the constructed strains, their growth on solid M9 minimal media with different carbon sources, and the detected level of PykF activity

\begin{tabular}{|c|c|c|c|c|}
\hline \multirow[t]{2}{*}{ Strain } & \multirow[t]{2}{*}{ Description } & \multicolumn{2}{|c|}{ Comparative growth on carbon source ${ }^{a}$} & \multirow{2}{*}{$\begin{array}{l}\mathrm{PykF}^{\mathrm{b}} \\
\mathrm{mU} / \mathrm{mg}\end{array}$} \\
\hline & & glucose & ribose & \\
\hline AK111 & MG1655 - wild type & +++++ & +++++ & NT \\
\hline AK011 & MG1655- $\Delta p y k A$ & NT & NT & NT \\
\hline AK101 & MG1655- $\Delta(e d d-e d a)$ & NT & NT & NT \\
\hline AK110 & MG1655- $\Delta p y k F$ & NT & NT & NT \\
\hline AK010 & MG1655- $\Delta(p y k A, p y k F)$ & NT & NT & NT \\
\hline AK000 & MG1655- $\Delta(p y k A$, edd-eda, $p y k F)$ & +++ & - & $5 \pm 5$ \\
\hline AK001 & MG1655- $\Delta(p y k A$, edd-eda $)$ & ++++ & ++++ & $590 \pm 30$ \\
\hline AK002 & AK001- $\left(p y k F \leftarrow[n u t L]-\mathrm{P}_{\mathrm{L}}\right)$ & +++ & - & $10 \pm 10$ \\
\hline AK003 & AK001- $\left(p y k F \leftarrow[r r n G-A T]-\mathrm{P}_{\mathrm{L}}\right)$ & +++ & - & $10 \pm 10$ \\
\hline AK004 & AK001- $\left(p y k F \leftarrow\left[r h o \_a\right]-[\right.$ nutL $\left.]-\mathrm{P}_{\mathrm{L}}\right)$ & ++++ & +++ & $480 \pm 20$ \\
\hline AK005 & AK001- $\left(p y k F \leftarrow\left[r h o \_a\right]-[r r n G-A T]-\mathrm{P}_{\mathrm{L}}\right)$ & +++ & - & $10 \pm 10$ \\
\hline AK006 & AK000::入cIts857 & & & \\
\hline AK007 & AK001::入cIts857 & & & \\
\hline AK008 & AK002::入cIts857 & & & \\
\hline AK009 & AK003::入cIts857 & & & \\
\hline
\end{tabular}

NT $=$ Not tested

${ }^{a}$ Growth response was observed after $48 \mathrm{~h}$ of cultivation at $37^{\circ} \mathrm{C}$ on solid $\mathrm{M} 9$ minimal medium supplemented with either glucose $(10 \mathrm{mM})$ or ribose $(15 \mathrm{mM})$ as the sole carbon source.

${ }^{\mathrm{b}}$ PykF activity was measured for the cells grown at $37^{\circ} \mathrm{C}$ in liquid M9 minimal medium with glucose.

Fig. 2. a General scheme of stepwise Red-driven modifications of the strains based on AK001 with pykF-wt. GenBank accession numbers for the nucleotide sequences of chromosomal DNA fragments downstream of the $p y k F$ gene are indicated below the names of the corresponding strains. AK002 was obtained by inserting the $\left(\mathrm{P}_{\mathrm{L}}-n u t L\right)$ carrier $\lambda \mathrm{DNA}$ fragment linked with excisable $\mathrm{Cm}^{\mathrm{R}}$, followed by curing the marker with $\lambda$ attB as a 'scar' sequence. The substitution of the $\operatorname{rrn} G-A T$ sequence for $n u t L$ was provided by the second Red modification, leading finally to the appearance of the second $\lambda a t t B$ scar in the chromosome of AK003. AK004 and AK005 were obtained from AK002 and AK003, respectively, by inserting a DNA fragment consisting of the Rhodependent transcription terminator rho_a [Albrechtsen et al., 1990]. b Structural details of the regulatory elements. The nucleotide sequence of $\lambda a t t B$ is depicted as double-stranded DNA. Two core-type targets for $\lambda$ Int-protein, $B$ and B', flanking the 'overlap region', $\mathrm{O}$, comprise $\lambda a t t B$. Relative orientation of the $\lambda$ Int bind- ing sites is shown by arrows under the corresponding nucleotides in $\lambda a t t B$ [Landy, 1989]. The probable, Rho-independent transcription terminator of $p y k F, \mathrm{~T}_{p y k F}$, is presented as the fragment of dsDNA, indicating the GC-rich inverted repeat and the (oligoT) tail in the sense strand. Features of the $\mathrm{P}_{\mathrm{L}}$ structure [Giladi et al., 1992, 1996], including the $\mathrm{P}_{\mathrm{L}} 1$ and $\mathrm{P}_{\mathrm{L}} 2$ promoters, together with the sites for the IHF binding $(\mathrm{L} 1, \mathrm{~L} 2)$ and the $\mathrm{O}_{\mathrm{L}}\left(\mathrm{O}_{\mathrm{L}} 1\right.$, $\mathrm{O}_{\mathrm{L}} 2$, and $\mathrm{O}_{\mathrm{L}} 3$ ) operators (the targets for $\lambda \mathrm{CI}$ ), are shown. The $\mathrm{P}_{\mathrm{L}^{-}}$ carrier DNA fragment that was initially inserted corresponded to the native $\lambda$ DNA from nucleotide -240 up to +118 (numbers denoting the distance from $\mathrm{P}_{\mathrm{L}} 1$ start site) and included the nutL site [Sanger et al., 1982]. The nucleotide sequences of $n u t L$ and $r r n G$ $A T$ are depicted as single-stranded DNA. The ability of boxB to form a stem-and-loop structure is noted by the inverted pointers, and the sequences of boxA and boxC are indicated in rectangles [Li et al., 1984]. 


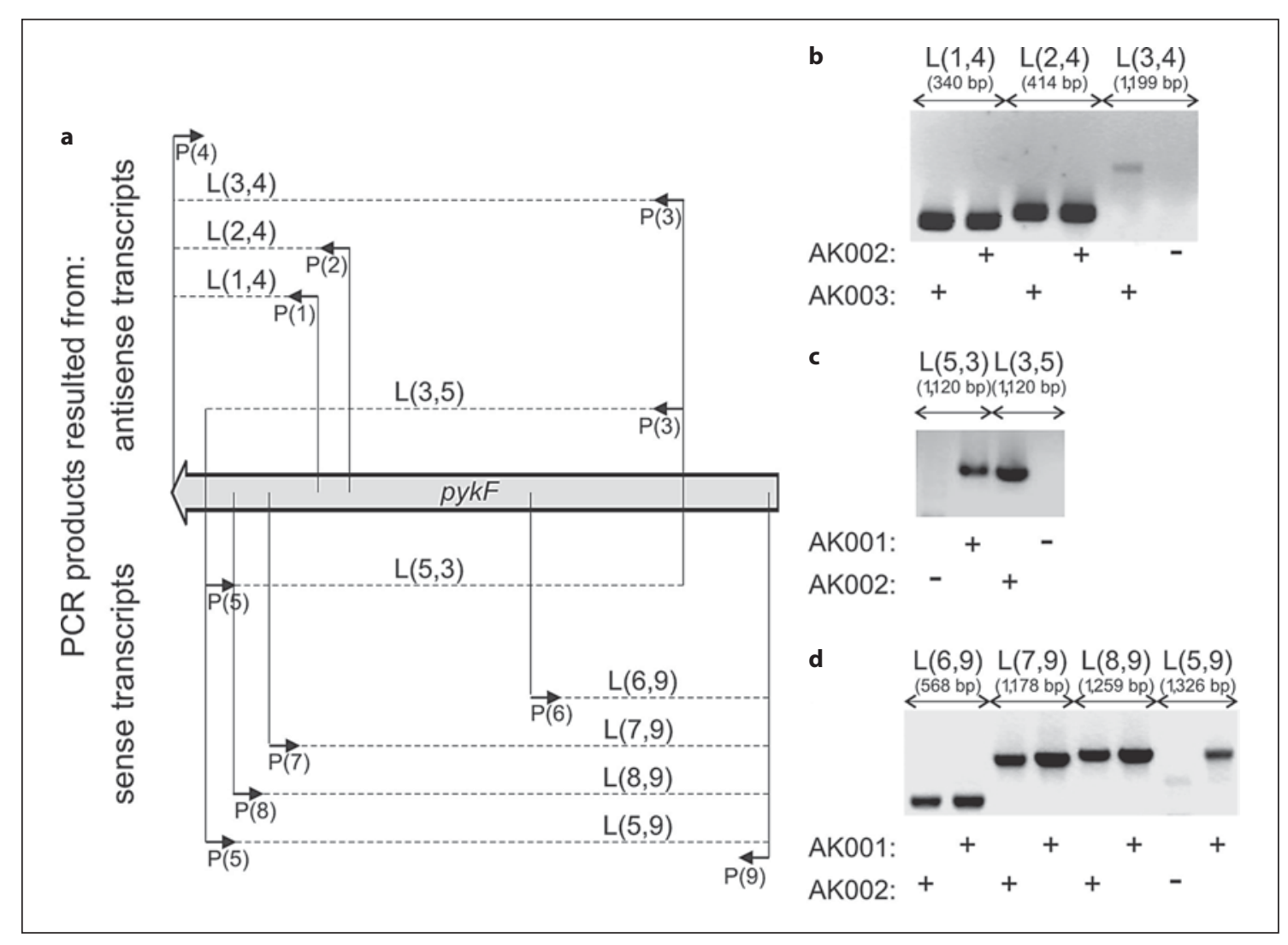

Fig. 3. a Experimental strategy and RT-PCR analysis of RNAs extracted from AK001, AK002, and AK003 strains. The possible amplimers $\mathrm{L}(i, j)$ obtained after exploiting $\mathrm{P}(i)$ as a primer for reverse transcription and $\mathrm{P}(j)$ for DNA amplification by RT-PCR are indicated. b Various amplimers corresponded to $\mathrm{P}_{\mathrm{L}}$-originated

phenotype achieved by constitutive $\mathrm{P}_{\mathrm{L}}$-driven convergent transcription. At the same time, the more efficient synthesis of $p y k F$ asRNA was detected by reverse transcription PCR (RT-PCR) in strain AK003, where it was originated from $\mathrm{P}_{\mathrm{L}^{-}}[\mathrm{rrnG}-A T]$, than in the case of $\mathrm{P}_{\mathrm{L}^{-}}[$nutL $]$in AK002 (fig. 3a, b). Indeed, rather short amplimers, $\mathrm{L}(1,4)$ and $\mathrm{L}(2,4)$ (up to $414 \mathrm{bp}$ ), corresponding to $5^{\prime}$-fragments of the $p y k F$ asRNA, were detected in extracts of both the AK002 and AK003 strains, but only AK003 retained asRNA extending from the $5^{\prime}$-terminus up to $1,199 \mathrm{nt}$ in length as the template for RT-PCR ${ }^{3}$.

3 Later, the presence of rather large (1,120 nt in length) L(3,5) amplimer, corresponding to the central part of asRNA pykF, was demonstrated in extracts of AK002 (see next section), but again the extended transcription originating from $\mathrm{P}_{\mathrm{L}}$ was more efficient in AK003 according to RT-PCR (data not shown).
asRNAs that were detected in the AK002 and AK003 strains. c Analyses of rather large fragments of sense and anti-sense $p y k F$ RNA. d RT-PCR-driven amplification of DNA fragments corresponded to mRNA that originated from the $p y k F$ start site and differed at the 3 '-terminus.

In turn, the AK004 and AK005 strains, based on AK002 and AK003, correspondingly, and possessing rho_a as a Rho-dependent terminator for $\mathrm{P}_{\mathrm{L}}$-mediated convergent transcription, significantly differed in $p y k F$ gene expression. AK004 ( $p y k F \leftarrow\left[\right.$ rho_a]-[nutL]- $\mathrm{P}_{\mathrm{L}}$ ) was able to grow on ribose as the carbon source and retained about $80-90 \%$ of the wild-type PykF activity (table 1), while AK005 $\left(p y k F \leftarrow\left[r h o \_a\right]-[r r n G-A T]-\mathrm{P}_{\mathrm{L}}\right)$ had significantly impaired growth on ribose, and its PYR kinase activity did not exceed $5 \%$ of the control. We concluded that the $p y k F$ silencing in the latter case was caused by the convergent transcription by RNAPs that were resistant to Rho-dependent termination [Albrechtsen et al., 1990, 1991].

\section{Decreased Level of Full-Sized mRNA Led to pykF Gene Silencing \\ RNA samples were prepared from the two strains, AK001 and AK002, with (pykF-wt) and with ( $p y k F \leftarrow$}


Fig. 4. a Structure of plasmid pPR53 [Mashko et al., 1990] carrying the cassette with the phage $\lambda$ cIts 857 gene and the gene for the hybrid Cro'-CAT protein under the transcriptional control of the $\lambda P_{R} / O_{R}$ regulatory region $\left(\mathrm{P}_{\mathrm{R}}\right)$. CAT is chloramphenicol acetyltransferase originally encoding by the cat gene from pBR325 [Bolivar, 1978]. The synthesis of the hybrid Cro'CAT and the full-sized CAT could be seen by gel electrophoresis among the total cellular proteins that were extracted from the thermo-induced, plasmid-carrying E. coli cells. b Principal scheme of the cassette integration from pPR53 into the $\phi 80$ attB site of the E. coli MG1655 chromosome according to the dual in/out strategy [Minaeva et al., 2008].
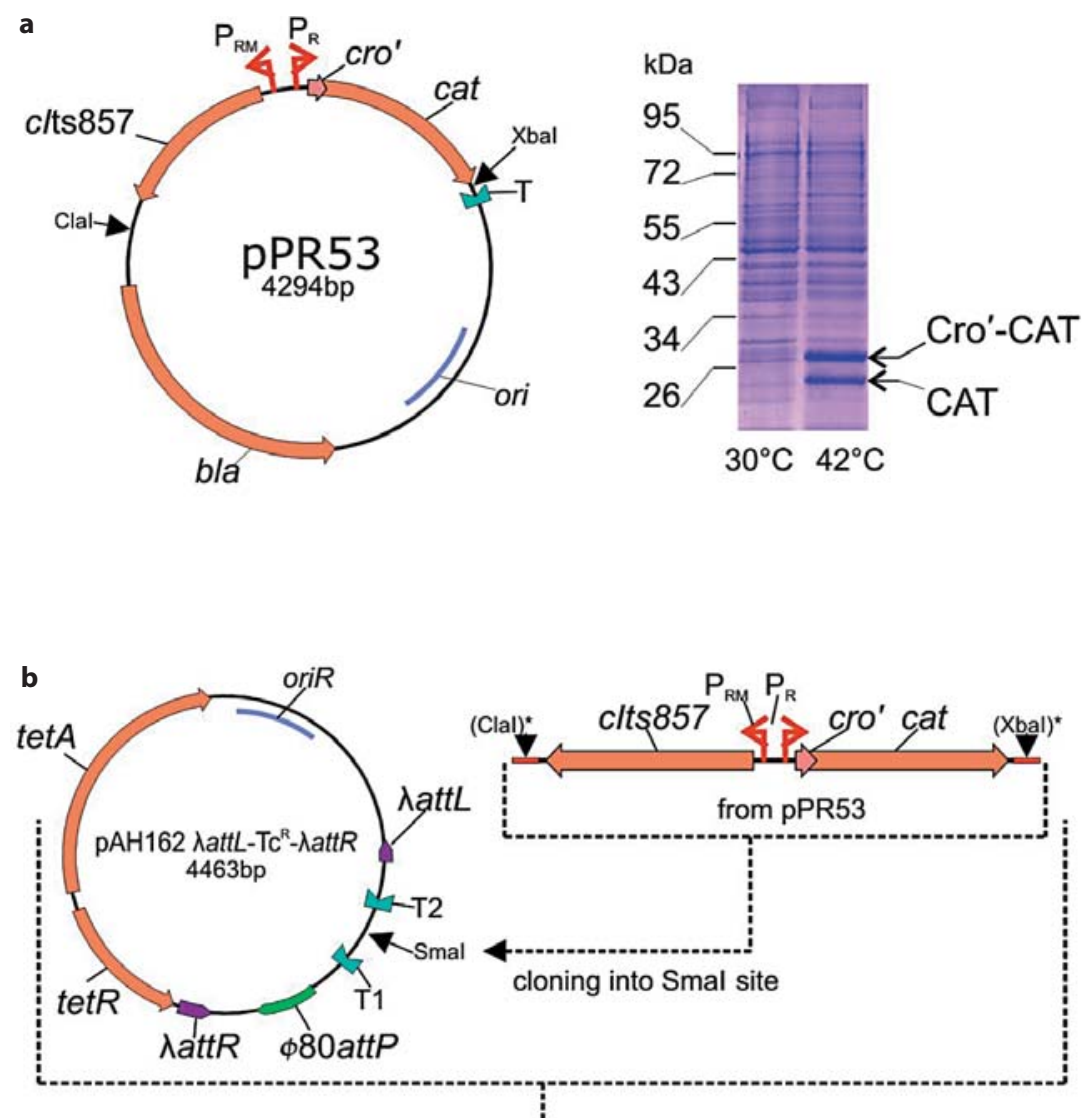

$\phi 80$-Int-driven integration into $\phi 80$ attB of $E$. coli chromosome followed by $\lambda$ Xis/Int-driven excision of the plasmid part with $\lambda$ attB as a 'scar'

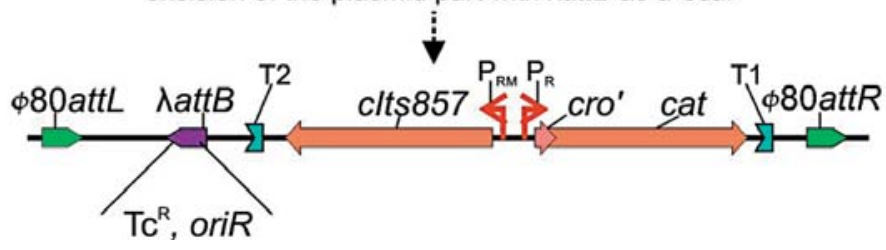

$\left.[n u t L]-\mathrm{P}_{\mathrm{L}}\right)$, correspondingly, grown on glucose, and $p y k F$ silencing was detected by RT-PCR according to the strategy presented in figure 3 a. The presence of 1,120 -nt fragments of mRNA and asRNA corresponding to the internal portion of the $p y k F$ gene was detected. The amplimers $\mathrm{L}(5,3)$ corresponded to mRNA fragments detected in the AK001 but not AK002 extracts. In contrast, $L(3,5)$ for the asRNAs was only found in AK002 (fig. 3c).

The synthesis of $p y k F$ mRNA in AK001 and AK002 was evaluated by RT-PCR to detect the set of 3'-truncated pykF mRNA fragments. $\mathrm{P} 6, \mathrm{P} 7, \mathrm{P} 8$, or $\mathrm{P} 5$ primers were used as different probes for CDNA synthesis, followed by PCR using P9 as the second primer for DNA amplifica- tion (fig. 3a). The set of $p y k F$ mRNA-mediated amplimers (up to $1,259 \mathrm{bp}$ in length) were detected for both strains, but the longest fragment $\mathrm{L}(5,9)(1,326 \mathrm{bp})$ could only be seen clearly in AK001 (fig. 3d). Therefore, $p y k F$ silencing in $\mathrm{AK} 002$ ( $p y k F \leftarrow[n u t L]-\mathrm{P}_{\mathrm{L}}$ ) results from a significantly decreased level of the full-sized mRNA present in the growing cells.

\section{Conditional pykF Silencing Is Dependent on the} Activity of $\lambda$ CIts 857

The $\left(\lambda c\right.$ Its $857-\mathrm{P}_{\mathrm{R}}>c r o^{\prime}$-cat $)$ cassette, taken from plasmid pPR53 [Mashko et al., 1990], provided the ts-dependent biosynthesis of the hybrid Cro'-CAT and the full- 
Fig. 5. Effect of conditional $p y k F$ silencing depended on the cultivation temperature of the cIts857 carrier cells. a Bacterial growth on ribose-containing agarose media. $\mathbf{b}$ Typical dependence of the specific CAT activity on the cultivation temperature is presented for AK007 for all four tested strains. c PYR kinase activities of the different strains show dependence on the cultivation temperature.
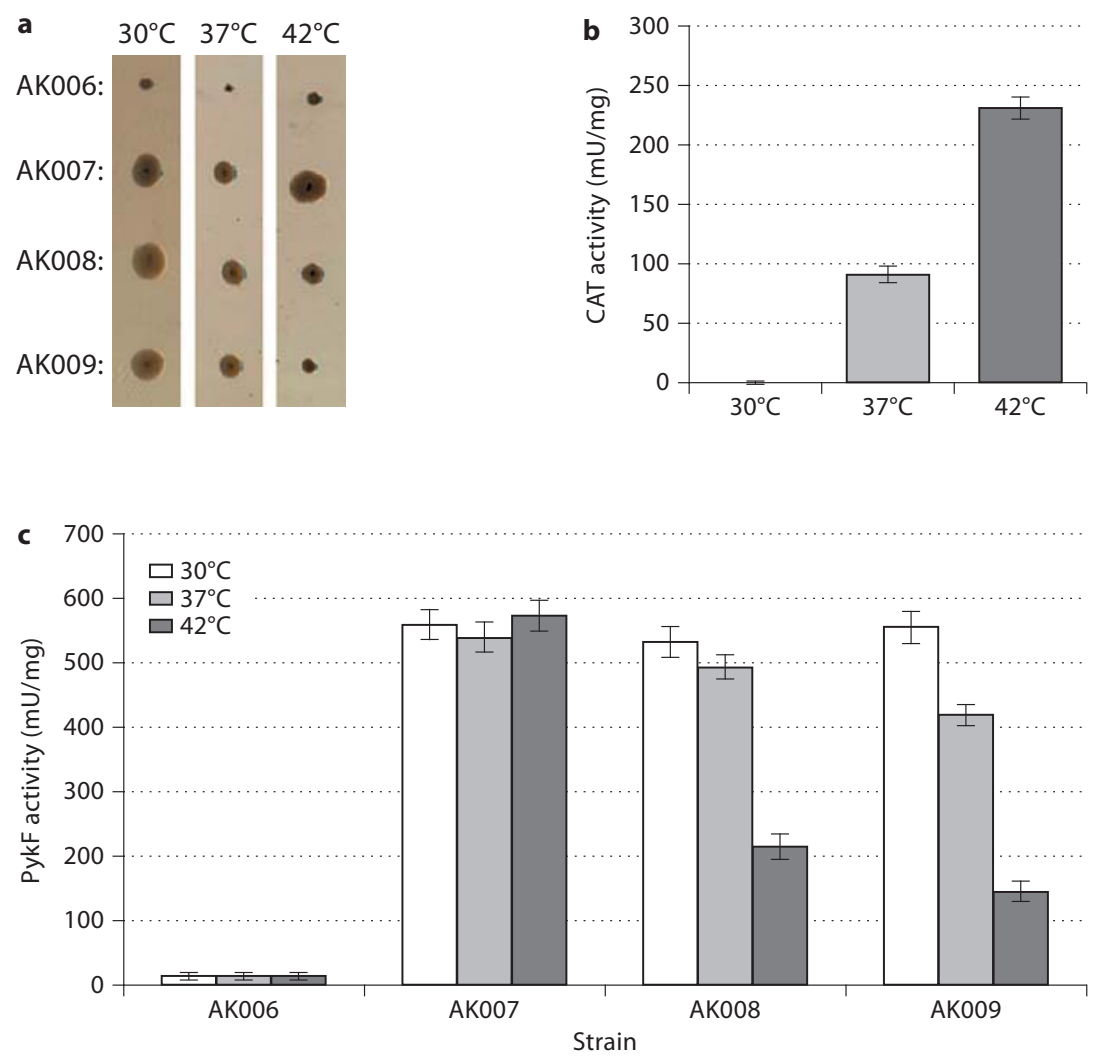

sized CAT protein (fig. 4a). Using a dual in/out strategy [Minaeva et al., 2008], this cassette was integrated at the $\phi 80 a t t B$ site of the E. coli MG1655 chromosome (fig. 4b) followed by P1vir phage-mediated generalized transduction (P1-duction) of the cassette to strains AK000, AK001, $\mathrm{AK} 002$, and AK003, each differing in the structure of the $p y k F$ gene, and four new strains were obtained, numbered from AK006 through AK009 (table 1). The growth of the cIts857 carrier strains was studied at different temperatures on agar plates with ribose. The levels of PYR kinase and CAT activities were determined in bacteria grown in liquid media with glucose. CAT was used as a distinctive reporter to evaluate ts-inducible $\mathrm{P}_{\mathrm{L}^{-}}$or $\mathrm{P}_{\mathrm{R}}$-mediated gene expression.

At $30^{\circ} \mathrm{C}$, when the repressor CIts 857 was active,

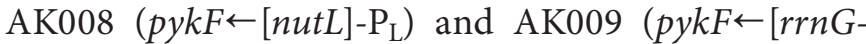
$A T]-\mathrm{P}_{\mathrm{L}}$ ) grew rather well on ribose, as did the ( $\left.p y k F-\mathrm{wt}\right)$ strain, AK007 (fig. 5a). From the CAT activity (fig. 5b), we concluded that stepwise increases in the cultivation temperature up to $42^{\circ} \mathrm{C}$ led to the gradual derepression of the $\mathrm{P}_{\mathrm{L}^{-}}$and $\mathrm{P}_{\mathrm{R}}$-promoters. The growth of the tested strains on ribose was different. AK008 retained the residual, but visible, capacity to grow on ribose even at $42^{\circ} \mathrm{C}$, although this growth was significantly worse than for the ( $p y k F$-wt)-carrying control. AK009 clearly manifested a conditionally-silenced $p y k F$ phenotype: it was practically indistinguishable from the AK007 at $30^{\circ} \mathrm{C}$, and it already had poor growth on ribose at $42^{\circ} \mathrm{C}$. The AK006 strain, carrying $\Delta p y k F$, had a similarly poor growth at $42^{\circ} \mathrm{C}$.

Increasing levels of CAT activity depended on increasing bacterial cultivation temperatures in all strains (fig. 5b). PykF activity responded differently: (a) its levels were almost identical at all temperatures in AK007 with pykF-wt, and (b) the obvious ts-dependent $p y k F$-silencing could be seen in the two strains with $\mathrm{P}_{\mathrm{L}}$-mediated convergent transcription (fig. $5 \mathrm{c}$ ). The value of specific PykF activity decreased with the cultivation time after thermoinduction for both AK008 ( $p y k F \leftarrow[n u t L]-\mathrm{P}_{\mathrm{L}}$ ) and

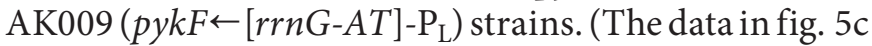


correspond to 3-3.5 h of cell growth at different experimental temperatures.) However, the detected level of PykF activity was lower for AK009 than for AK008 at early stages of cell cultivation at 37 and $42^{\circ} \mathrm{C}$ (data not shown). Thus, convergent transcription, protected from Rho-dependent termination, led to a more efficient conditional $p y k F$ gene silencing.

\section{Discussion}

Integration of the CIts857-governed, $\mathrm{P}_{\mathrm{L}}$ downstream pykF, face-to-face with its native promoter, led to conditional gene silencing. With constitutive $\mathrm{P}_{\mathrm{L}}$-mediated convergent transcription, the basal level of PykF activity did not exceed $5 \%$ of that seen in the wild type. This effect could result from the following: (a) cis-encoded asRNA hybridization with mRNA; (b) impaired mRNA transcription caused by TI between converging RNAPs, or (c) both of these mechanisms. These mechanisms are frequently considered in relation to the results of convergent transcription [Elledge and Davis, 1989; O'Connor and Timmis, 1987].

The majority of natural cis-encoded asRNAs are small ( 50-300 nt), highly structured molecules that bind their target RNAs, thereby regulating target gene expression [Brantl, 2007]. For proper inhibition, the asRNA molar concentration must be in significant excess over that of the target [Brantl and Wagner, 1996; Brenner and Tomizawa, 1991; Nakashima and Tamura, 2009]. The hybridization between asRNA and mRNA occurs via a complex pathway that usually has several steps and is initiated by specifically arranged complementary structures [reviewed in Brantl, 2002, 2007].

Thus, we doubted that the strong $p y k F$ silencing resulted from the inhibitory effect of cis-encoded asRNA, which would need to hybridize with mRNA without any specific targeting. On the other hand, the repression potential of TI caused by converging RNAPs may be very large (over a 100-fold range) [Elledge and Davis, 1989]. Moreover, there was a strikingly strong dependence upon convergent promoters strength for the TI-driven repression; changes in promoter initiation rates of two- or threefold often had profound effects. Indeed, a rather high residual activity of PykF was detected in the present study at moderate temperatures around $37^{\circ} \mathrm{C}$ (fig. 5). This partial derepression of the $\mathrm{P}_{\mathrm{L}}$-mediated transcription was equivalent to the decreased quasi-strength of the convergent promoter.

pykF Silencing Caused by Nonterminated Convergent Transcription
The detection of 5 '-proximal fragments of $p y k F m R N A$ in the silenced conditions can be explained by two molecular mechanisms. Regarding specific effects of cis-encoded asRNA, the RNase-mediated fast degradation of the duplex may have occurred between asRNA and the 3 '-end of the mRNA, whereas if TI played the main role in $p y k F$ silencing, the head-on EC collision mechanism between the converging RNAPs may have led to formation of the truncated mRNA of the target gene. Certainly, the two other known TI mechanisms, 'promoter occlusion' and 'sitting duck' interference, where mRNA synthesis cannot be initiated, may additionally increase the efficiency of silencing. Indeed, the existing theoretical models of TI mention the great impact of EC collisions on the interference efficiency not only when the 'aggressive' convergent promoter is very strong but also when the interfering promoters are far apart [Sneppen et al., 2005].

At present, it is impossible to investigate the fate of the RNAPs once they have undergone collision. In vitro, both RNAPs, which are in converging complexes that have collided, usually stall against each other and remain bound to the DNA [Crampton et al., 2006]. At the same time, the simplest explanation of the in vivo reversibility of TI [Ward and Murray, 1979] is that both of the RNAPs that have collided are released from the DNA template. However, the available data to date do not exclude the possibility that in each EC collision only one RNAP dissociates based on the complex stability. The complexes are not equivalent even in vitro because regulation of transcription elongation appears to be governed by the ability of RNAP to adopt multiple conformational states that are induced, in particular, by template DNA and binding NTP [Foster et al., 2001]. The asymmetry of the TI could be significantly enhanced in vivo in the presence of different transcription elongation factors [Borukhov et al., 2005], due to the possible cooperative 'push' from following RNAPs that depends on the density of elongating complexes [Epshtein et al., 2003; Epshtein and Nudler, 2003]. It could also be enhanced when asRNA-synthesizing RNAPs are much more sensitive to possible Rho-dependent termination [Banerjee et al., 2006; Nudler and Gottesman, 2002] than RNAPs participating in mRNA synthesis, usually coupled with translation in the bacterial cell.

In this study, efficient $p y k F$ silencing was initially achieved by constitutive $\mathrm{P}_{\mathrm{L}}$-mediated convergent transcription. The frequency of transcription initiation from $\mathrm{P}_{\mathrm{L}}$ is in the range of 5-15 transcripts/min [Liang et al., 1999], the mRNA chain elongation rate is in the range

J Mol Microbiol Biotechnol 2010;18:1-13 
40-55 nt/s [Bremer and Dennis, 1996], and the length of the $p y k F$ mRNA is approximately $1,700 \mathrm{nt}$. From these facts, we expect that about 3-10 RNAPs participate in the convergent transcription at any given moment; thus, each could collide with RNAPs originating from $p y k F$ mRNA synthesis if the EC collision frequency depends only on the strength of convergent promoters. It could be further proposed that the ECs were equivalent and at least one, or possibly both, of the RNAPs that collided then dissociated from the template with equal probability. However, the following facts then cannot be explained: (a) the detection of rather large $3^{\prime}$-truncated, pykF mRNA fragments (with $\mathrm{L}>1,200 \mathrm{nt}$ ) in AK002 $\left(p y k F \leftarrow[n u t L]-\mathrm{P}_{\mathrm{L}}\right)$, and (b) the slight decrease in the $p y k F$ expression level that was detected in cIts857 carrier strains AK008 ( $\left.p y k F \leftarrow[n u t L]-\mathrm{P}_{\mathrm{L}}\right)$ relative to AK009

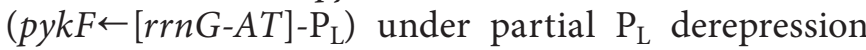
conditions.

TI could be completely abolished if a fraction of the converging RNAPs terminated transcription in an untimely manner and did not participate in EC collisions. Such transcription attenuation would be formally equivalent to a significant decrease in the convergent promoter strength.

$\mathrm{P}_{\mathrm{L}}$ was inserted downstream of the putative Rho-independent $p y k F$ terminator (fig. 2). According to the known computer algorithms [Kingsford et al., 2007; Lesnik et al., 2001] we did not find clear Rho-independent terminators for the convergent transcription of $p y k F^{4}$, but the transcription might still be terminated by the Rho-dependent mechanism.

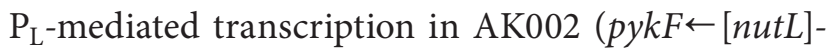
$\mathrm{P}_{\mathrm{L}}$ ) was not protected by the $\lambda \mathrm{N}$ anti-terminating system [Chattopadhyay et al., 1995; Mogridge et al., 1995, 1998], as was in a previous study [Ward and Murray, 1979]. At the same time, the $\lambda$ boxA from the nutL site in the $\left(\mathrm{P}_{\mathrm{L}^{-}}\right.$ $n u t L$ )-carrier constructions (fig. 2) seemed to closely resemble the rrn boxA which, in turn, was shown to be sufficient to prevent Rho-dependent termination [Condon et al., 1995; Squires et al., 1993]. Nevertheless, inserting rho_a interrupted the effect of $p y k F$ silencing in AK004, where $\mathrm{P}_{\mathrm{L}}$-nut $L$ was responsible for convergent transcription. However, this terminator only slightly decreased the

\footnotetext{
4 The native Rho-independent terminator of the pykF gene was calculated to possess a rather high 'termination score' even for convergent transcription, according to the algorithm developed by Kingsford et al. [2007].
}

level of $p y k F$ silencing in AK005, where the $5^{\prime}$-terminus of the $\mathrm{P}_{\mathrm{L}}$-originating nascent RNA carried the $r r n G-A T$ sequence. These data correlated with the known findings that just a slight difference in boxA sequences finally determined the assembly pathways leading to the controlled formation of different RNA protein anti-termination complexes involved in vivo in the transcription of the $\mathrm{rrn}$ genes or in $\mathrm{N}$-dependent phage $\lambda$ development [Greive et al., 2005; Luo et al., 2008].

It seems that transcription initiated in the bacterial chromosome and protected by $\lambda \mathrm{N}$-mediated or other systems, which could override all types of terminators [King et al., 1996; Marr et al., 2001; Nickels et al., 2002; Oberto et al., 1993], might be toxic for the cell. Nevertheless, the conversion of converging RNAP to a form that is only resistant to Rho-dependent termination was considered to be a reasonable hypothesis for the improvement of the gene silencing effect caused by artificial convergent transcription. Comparing the effects of $p y k F$ silencing for

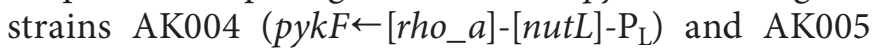
$\left(p y k F \leftarrow\left[r h o \_a\right]-[r r n G-A T]-\mathrm{P}_{\mathrm{L}}\right)$, we conclude that our results confirm this proposal. Untimely termination of convergent transcription, which often occurs, may explain why such an obvious, TI-based approach has not yet received broad application for target-gene silencing in molecular microbiology.

TI caused by EC collisions between converging RNAPs is the most probable reason for the $p y k F$ silencing that was detected. Nevertheless, our results could not conclusively rule out a role for strictly cis-asRNA effects. Even in the latter case, efficient, anti-terminated, engineered asRNA synthesis seems essential. Therefore, we recommend this novel design using convergent transcription that is protected from Rho-dependent termination to silence any gene target. It may be especially useful when stationary, growth-dependent [Miksch et al., 2005] and/or metabolically regulated promoters of moderate strength [Farmer and Liao, 2000], not as 'aggressive' as $\mathrm{P}_{\mathrm{L}}$, are used as the convergent silencers.

\section{Experimental Procedure}

Recombinant DNA Techniques, Bacterial Strains and Growth Condition

Construction and restriction analysis of the recombinant DNAs, agarose gel electrophoresis, $\mathrm{Ca}^{2+}$-dependent transformation, and electroporation of E. coli cells were all carried out using routine experimental protocols [Sambrook and Russell, 2001]. Restriction endonucleases, T4 DNA ligase (Fermentas, Lithuania), and AccuTaq DNA polymerase (Sigma, USA) were used according to the manufacturer's instructions. Sigma products were 
used to isolate plasmid DNA and extract DNA fragments from agarose gels.

All of the strains tested were derived from E. coli MG1655 as follows: (a) Red modifications of the chromosome were prepared according to Datsenko and Wanner [2000], exploiting the phage $\lambda$ site-specific Xis/Int system instead of FLP recombinase, as described earlier [Doroshenko et al., 2007]; (b) the $\lambda$ cIts857 carrier cassette from pPR53 [Mashko et al., 1990] (fig. 4a) was inserted into the native $\phi 80$ att $B$ site of the $E$. coli MG1655 genome according to Minaeva et al. [2008] (fig. 4b), followed by a combining of the chromosomal modifications using (c) P1-duction [Miller, 1972]. The plasmid pKD46 [Datsenko and Wanner, 2000], carrying arabinose-inducible $\lambda$ Red genes, was used to provide the Red recombination. The pMW118- $\lambda$ att $L-\mathrm{Cm}^{\mathrm{R}}-\lambda a t t R$ [Katashkina et al., 2005], $\lambda$ cIts857 DNA (Fermentas), and chromosomal DNA from $E$. coli MG1655 were used as templates to construct amplimers with excisable $\mathrm{Cm}^{\mathrm{R}}, \mathrm{P}_{\mathrm{L}}$-promoters and with $\mathrm{rrnG}$-AT sequence, respectively. Plasmid pMW- $\lambda$ int-xis [Doroshenko et al., 2007] encoding the $\lambda X$ is/Int recombinase was used to eliminate all DNA fragments that were flanked by $\lambda a t t L / R$ sites at the final steps of the chromosomal modifications. For $\phi 80$-driven integration, plasmids pAH123 ([Haldimann and Wanner, 2001] GenBank accession number AY048726) and pAH162- $\lambda$ att $L-\mathrm{Tc}^{\mathrm{R}}-\lambda$ attR [Minaeva et al., 2008] were used as the 'helper' plasmid and 'integrative vector' [Minaeva et al., 2008], respectively. The latter plasmid possessed a $\mathrm{Pir}^{+}$-dependent replication function [Bowers et al., 2007]; therefore, the E. coli CC118 $\lambda$ pir $^{+}$strain [Herrero et al., 1990] was used as a recipient and as a host strain for propagation of the conditionally replicated recombinant plasmids constructed using this vector.

Several steps were required to insert $\mathrm{P}_{\mathrm{L}}$ downstream of $p y k F$, followed by the introduction of $r r n G-A T$ and rho_a sequences. DNA fragments ' $\left(\lambda a t t R-C m^{\mathrm{R}}-\lambda a t t L\right)-\mathrm{P}_{\mathrm{L}}$ ' and ' $\left(\lambda a t t R-\mathrm{Cm}^{\mathrm{R}}-\lambda a t t L\right)$ ( $r n$ G-AT)' were obtained by PCR using DNA fragments containing one of the regulatory elements and the excisable $\mathrm{Cm}^{\mathrm{R}}$ as the selective marker. The linkage of ' $\left(\lambda a t t R-\mathrm{Cm}^{\mathrm{R}}-\lambda a t t L\right)-\mathrm{P}_{\mathrm{L}}$ ' was provided by ligation of the KpnI-produced ends of the amplimers, and $B g l \mathrm{II}$ was used for the joining of ' $\left(\lambda a t t R-\mathrm{Cm}^{\mathrm{R}}-\lambda a t t L\right)-(r r n G$ $A T)^{\prime}$ that followed. These restriction sites were predesigned into the corresponding PCR primers. The DNA fragments obtained were introduced by the Red system, downstream of the $p y k F$ gene in the E. coli MG1655 chromosome (fig. 2). The marker was excised from the chromosome to complete the desired rearrangements. The residual $\lambda a t t B$ site was the 'scar' sequence at each step of such marker curing. Later, the amplimer with rho_a was also inserted. The structures of all stepwise Red-inserted DNA fragments were confirmed using PCR-mediated sequencing.

Primers that were used to delete genes were designed to replace almost all of the coding sequences (usually 12 codons from both ends were retained) of each gene/operon with the excisable $\mathrm{Cm}^{\mathrm{R}}$ marker. The deletions marked by $\mathrm{Cm}^{\mathrm{R}}$ were transferred using $\mathrm{P} 1-$ duction followed by $\lambda \mathrm{Xis} /$ Int-dependent excising of the marker to combine the mutations in one strain. The resulting mutants were checked by PCR to confirm their genetic structure. Primers were designed to provide the deletions 'in frame' after excising the marker and preserving the $\lambda a t t B$ site as the scar sequence. The sequences of these primers are available from the corresponding author.

Bacteria were grown on M9 minimal media agar [Sambrook and Russell, 2001], supplemented with glucose (10 mM) or ribose
(15 mM) as the sole carbon source. Bacteria were alternatively cultivated in LB broth or M9 minimal glucose-containing liquid media. Ampicillin $(100 \mathrm{mg} / \mathrm{l})$ was added to maintain the $A p^{\mathrm{R}}$ plasmid carrier strains. Chloramphenicol $(25 \mathrm{mg} / \mathrm{l})$ or tetracycline $(12.5$ $\mathrm{mg} / \mathrm{l}$ ) was added to media as required to select for the corresponding markers in the bacterial chromosome.

\section{Reverse Transcription PCR}

RT-PCR was performed as previously described [Doroshenko et al., 2007]. Briefly, total RNA was isolated from E. coli cells, its concentration was determined using the absorbance at $260 \mathrm{~nm}$, the RNA integrity was monitored electrophoretically, reverse transcription of $p y k F$ RNA was carried out, and the resulting cDNA was subsequently amplified by PCR using different primers designed for testing $p y k F$ cognate RNAs, as presented in figure 3a. The following primers were used:

$$
\begin{aligned}
& \mathrm{P}(1): 5^{\prime} \text { - atgccgtggtgccgttgaaa } \rightarrow 3^{\prime} ; \\
& \mathrm{P}(2): 5^{\prime} \text { - cgtaccgaccgcgtgatgaa } \rightarrow 3^{\prime} ; \\
& \mathrm{P}(3): 5^{\prime} \text { - tccgcaccatgaaactggaaggcgg } \rightarrow 3^{\prime} ; \\
& \mathrm{P}(4): 5^{\prime} \text { - ttacaggacgtgaacagatgcg } \rightarrow 3^{\prime} ; \\
& \mathrm{P}(5): 5^{\prime} \text { - ttgtgtgccagaccgctctgc } \rightarrow 3^{\prime} ; \\
& \mathrm{P}(6): 5^{\prime} \text { - ggaagcagcaacaaagtctacg } \rightarrow 3^{\prime} ; \\
& \mathrm{P}(7): 5^{\prime} \text { - tggtggcatccgggaagtattt } \rightarrow 3^{\prime} ; \\
& \mathrm{P}(8): 5^{\prime} \text { - tctctttaacaagctgcggcacaa } \rightarrow 3^{\prime} ; \\
& \mathrm{P}(9): 5^{\prime} \text { - gaccaaaattgttgcaccatcgg } \rightarrow 3^{\prime} .
\end{aligned}
$$

Equal quantities (about $100 \mathrm{ng}$ ) of the total RNA were used to prepare cDNA for comparative evaluations, and the final PCRamplified DNA probes that were loaded on the gels were additionally normalized using the rrs $A$ gene (encoding $16 \mathrm{~S}$ rRNA) as an internal control in each sample. The reproducibility of this procedure was determined by performing two separate cDNA synthesis experiments using the RNA extracted for each strain. Similar results were obtained for the qualitative transcription levels of each of these duplicate experiments.

Control reactions to monitor DNA contamination were conducted with prepared RNAs in mock RT reactions without the presence of AMV reverse transcriptase.

\section{Enzyme Assays}

Overnight cultures of the strains grown on M9 minimal liquid medium with glucose at $30^{\circ} \mathrm{C}$ were diluted to a starting $\mathrm{OD}_{595}$ of 0.1 , and the cells were grown at different experimental temperatures up to $\mathrm{OD}_{595} \sim(0.5-0.6)$, harvested, washed, and sonicated. Spectrophotometric measurements were made using a Synergy 2 multi-detection microplate reader (BioTek Instruments, Inc., USA). Total protein concentration was determined using the BioRad Protein Assay (Bio-Rad, USA) in accordance with the manufacturer's instructions.

PykF activity was measured from the production of PYR in a coupled system with lactate dehydrogenase (LDH) and NADH [Malcovati and Valentini, 1982]. The reaction buffer contained $100 \mathrm{~mm}$ Tris- $\mathrm{HCl} \mathrm{pH} \mathrm{7.5,} 10 \mathrm{~mm} \mathrm{KCl,} 15 \mathrm{~mm} \mathrm{MgCl}_{2}, 5 \mathrm{~mm} \mathrm{ADP}$, $0.15 \mathrm{~mm}$ NADH, $10 \mathrm{U} / \mathrm{ml} \mathrm{LDH}, 1 \mathrm{mM}$ fructose-1,6-biphosphate, and $1 \mathrm{mM}$ PEP. All reagents were purchased from Sigma. PYR kinase activity was measured spectrophotometrically by the reduction in NADH in the probes.

CAT activity was assayed according to the standard spectrophotometric method [Shaw, 1975] based on detection of produced 
thionitrobenzoic acid at $412 \mathrm{~nm}$, as described in detail by Minaeva et al. [2008].

One unit of specific enzyme activity was defined as the amount of enzyme required to convert $1 \mu \mathrm{mol}$ substrate into the specific product per minute per milligram of protein. Each measurement was performed in triplicate.

\section{SDS-PAGE of the Cellular Proteins}

Protein electrophoresis was performed in $0.1 \%$ SDS-12\% PAGE

[Laemmli, 1970] followed by staining with Coomassie R-250.

\section{References}

-Adhya S, Gottesman M: Promoter occlusion: transcription through a promoter may inhibit its activity. Cell 1982;29:939-944.

-Albrechtsen B, Ross BM, Squires C, Squires CL: Transcriptional termination sequence at the end of the Escherichia coli ribosomal RNA G operon: complex terminators and antitermination. Nucleic Acids Res 1991;19:18451852.

Albrechtsen B, Squires CL, Li S, Squires C: Antitermination of characterized transcriptional terminators by the Escherichia coli rrnG leader region. J Mol Biol 1990;213:123-134.

Banerjee S, Chalissery J, Bandey I, Sen R: Rhodependent transcription termination: more questions than answers. J Microbiol 2006;44: 11-22.

Bolivar F: Construction and characterization of new cloning vehicles. III. Derivative of plasmid pBR322 carrying unique EcoRI sites for selection of EcoRI-generated recombinant DNA molecules. Gene 1978;4:121-136.

Borukhov S, Lee J, Laptenko O: Bacterial transcription elongation factors: new insights into molecular mechanism of action. Mol Microbiol 2005;55:1315-1324.

Bowers LM, Krüger R, Filutowicz M: Mechanism of origin activation by monomers of R6K-encoded $\pi$ protein. J Mol Biol 2007;368: 928-938.

Brantl S: Antisense-RNA regulation and RNA interference. Biochim Biophys Acta 2002; 1575:15-25.

Brantl S: Regulatory mechanisms employed by cis-encoded antisense RNAs. Curr Opin Microbiol 2007;10:102-109.

Brantl S, Wagner EG: An unusually long-lived antisense RNA in plasmid copy number control: in vivo RNAs encoded by the streptococcal plasmid pIP501. J Mol Biol 1996;255: 275-288.

Bremer H, Dennis PP: Modulation of chemical composition and other parameters of the cell by growth rate; in Neidhardt F (ed): Escherichia coli and Salmonella: Cellular and Molecular Biology, ed 2. Washington, ASM Press, 1996, pp 1553-1569.

Brenner M, Tomizawa J: Quantitation of ColE1encoded replication elements. Proc Nat Acad Sci USA 1991;88:405-409.

-Callen BP, Shearwin KE, Egan JB: Transcriptional interference between convergent promoters caused by elongation over the promoter. Mol Cell 2004;14:647-656.
Chattopadhyay S, Garcia-Mena J, DeVito J, Wolska K, Das A: Bipartite function of a small RNA hairpin in transcription antitermination in bacteriophage lambda. Proc Natl Acad Sci USA 1995;92:4061-4065.

Cheng R, Miao C, Gong Q, Gu Y, Lu X, Han F, Yu W: Specific gene silencing by artificial trans-encoded small noncoding RNAs in bacteria. Nucl Acids Res DOI:10.1093/nar/ gkp447.

Condon C, Squires C, Squires CL: Control of rRNA transcription in Escherichia coli. Microbiol Rev 1995;59:623-645.

Crampton N, Bonass WA, Kirkham J, Rivetti C, Thomson NH: Collision events between RNA polymerases in convergent transcription studied by atomic force microscopy. Nucl Acids Res 2006;34:5416-5425.

Datsenko KA, Wanner BL: One-step inactivation of chromosomal genes in Escherichia coli K12 using PCR products. Proc Natl Acad Sci USA 2000;97:6640-6645.

Daugherty BL, Hotta K, Kumar C, Ahn YH, Zhu JD, Pestka S: Antisense RNA: effect of ribosome binding sites, target location, size and concentration of specific mRNA molecules. Gene Anal Tech 1989;6:1-16.

Desai RP, Papoutsakis ET: Antisense RNA strategies for metabolic engineering of Clostridium acetobutylicum. Appl Environ Microbiol 1999;65:936-945.

Deuschle U, Kammerer W, Gentz R, Bujard H: Promoters of Escherichia coli: a hierarchy of in vivo strength indicates alternate structures. EMBO J 1986;5:2987-2994.

Doroshenko V, Airich L, Vitushkina M, Kolokolova A, Livshits V, Mashko S: YddG from Escherichia coli promotes export of aromatic amino acids. FEMS Microbiol Lett 2007;275: 312-318.

-Elledge SJ, Davis RW: Position and density effects on repression by stationary and mobile DNA-binding proteins. Genes Dev 1989;3: 185-197.

Engdahl HM, Hjalt TA, Wagner EG: A two unit antisense RNA cassette test system for silencing of target genes. Nucleic Acids Res 1997;25:3218-3227.

Engdahl HM, Lindell M, Wagner EG: Introduction of an RNA stability element at the $5^{\prime}$ end of an antisense RNA cassettes increases the inhibition of target RNA translation. Antisense Nucleic Acids Drug Dev 2001;11:2940.

-Epshtein V, Nudler E: Cooperation between RNA polymerase molecules in transcription elongation. Science 2003;300:801-805.
Epshtein V, Toulmé F, Rahmouni AR, Borukhov $S$, Nudler E: Transcription through the roadblocks: the role of RNA polymerase cooperation. EMBO J 2003;22:4719-4727.

Farmer WR, Liao JC: Improving lycopene production in Escherichia coli by engineering metabolic control. Nat Biotechnol 2000;18: $533-537$.

Foster JE, Holmes SF, Erie DA: Allosteric binding of nucleoside triphosphates to RNA polymerase regulates transcription elongation. Cell 2001;106:243-252.

$\checkmark$ Giladi H, Igarashi K, Ishihama A, Oppenheim $\mathrm{AB}$ : Stimulation of the phage $\lambda \mathrm{pL}$ promoter by integration host factor requires the carboxy terminus of the $\alpha$-subunit of RNA polymerase. J Mol Biol 1992;227:985-990.

Giladi H, Murakami K, Ishihama A, Oppenheim AB: Identification of an UP element within the IHF binding site at the $\mathrm{P}_{\mathrm{L}} 1-\mathrm{P}_{\mathrm{L}} 2$ tandem promoter of bacteriophage $\lambda$. J Mol Biol 1996;260:484-491.

Gosset G, Yong-Xiao J, Berry A: A direct comparison of approaches for increasing carbon flow to aromatic biosynthesis in Escherichia coli. J Ind Microbiol 1996;17:47-52.

Greenblatt J, Nodwell JR, Mason SW: Transcriptional antitermination. Nature 1993;364: 401-406.

Greive SJ, Lins AF, von Hippel PH: Assembly of an RNA-protein complex. Binding of NusB and NusE (S10) proteins to boxA RNA nucleates the formation of the antitermination complex involved in controlling rRNA transcription in Escherichia coli. J Biol Chem 2005;280:36397-36408.

Haldimann A, Wanner BL: Conditional-replication, integration, excision, and retrieval plasmid-host systems for gene structurefunction studies of bacteria. J Bacteriol 2001; 183:6384-6393

Herrero M, de Lorenzo V, Timmis KN: Transposon vectors containing non-antibiotic resistance selection markers for cloning and stable chromosomal insertion of foreign genes in gram-negative bacteria. J Bacteriol 1990; 172:6557-6567.

Imaizumi A, Airikh LG, Doroshenko VG, Tsyrenzhapova IS: The method for producing of L-amino acid. WO 2007/088977 A1, PCT/JP2007/051815, 2007.

Ji Y, Yin D, Fox B, Holmes DJ, Payne D, Rosenberg M: Validation of antibacterial mechanism of action using regulated antisense RNA expression in Staphylococcus aureus. FEMS Microbiol Lett 2004;231:177-184. 
Katashkina JI, Skorokhodova AY, Zimenkov DV, Gulevich AY, Minaeva NI, Doroshenko VG, Biryukova IV, Mashko SV: Tuning of expression level of the genes of interest located in the bacterial chromosome. Mol Biol (Moscow) 2005;39:823-831.

- Kemmer C, Neubauer P: Antisense RNA based down-regulation of RNAseE in E. coli. BMC Microbiol Cell Fact 2006;5:38.

Kim JY, Cha HJ: Down-regulation of acetate pathway through antisense strategy in Escherichia coli: improved foreign protein production. Biotechnol Bioengineer 2003;83: 841-853.

Kim PJ, Lee DY, Kim TY, Lee KH, Jeong H, Lee SY, Park S: Metabolite essentiality elucidates robustness of Escherichia coli metabolism. Proc Natl Acad Sci USA 2007;104:1363813642.

-King RA, Banik-Maiti S, Jin DJ, Weisberg RA: Transcripts that increase the processivity and elongation rate of RNA polymerase. Cell 1996;87:893-903.

-Kingsford CL, Ayanbule K, Salzberg SL: Rapid, accurate, computational discovery of Rhoindependent transcription terminators illuminates their relationship to DNA uptake. Genome Biol 2007;8:22.

Laemmli UK: Cleavage of structural proteins during the assembly of the head of bacteriophage T4. Nature 1970;227:680-685.

Landy A: Dynamic, structural, and regulatory aspects of $\lambda$ site-specific recombination. Annu Rev Biochem 1989;58:913-949.

Lesnik EA, Sampath R, Levene HB, Henderson TJ, McNeil JA, Ecker DJ: Prediction of rhoindependent transcriptional terminators in Escherichia coli. Nucl Acids Res 2001;29: 3583-3594.

Li SC, Squires CL, Squires C: Antitermination of E. coli rRNA transcription is caused by a control region segment containing lambda nutlike sequences. Cell 1984;38:851-860.

Liang ST, Bipatnath M, Xu YC, Chen SL, Dennis P, Ehrenberg M, Bremer H: Activities of constitutive promoters in Escherichia coli. J Mol Biol 1999;292:19-37.

Liu YS, Zhang YQ, Yang LX, Yao TJ, Xiao CL: Gene-specific silencing induced by parallel complementary RNA in Pseudomonas aeruginosa. Biotechnol Lett 2009;31:1571-1575.

Luo X, Hsiao H-H, Bubunenko M, Weber G, Court DL, Gottesman ME, Urlaub H, Wahl MC: Structural and functional analysis of the E. coli NusB-S10 transcription antitermination complex. Mol Cell 2008;32:791-802.

-Malcovati M, Valentini G: AMP- and fructose 1,6-bisphosphate-activated pyruvate kinases from Escherichia coli. Methods Enzymol 1982;90:170-179.

- Marr MT, Datwyler SA, Meares CF, Roberts JW: Restructuring of an RNA polymerase holoenzyme elongation complex by lambdoid phage Q proteins. Proc Natl Acad Sci USA 2001;98:8972-8978.
Mascarenhas D, Ashworth DJ, Chen CS: Deletion of $p g i$ alters tryptophan biosynthesis in genetically engineered strain of Escherichia coli. Appl Environm Microbiol 1991;57: 2995-2999.

Mashko SV, Veiko VP, Lapidus AL, Lebedeva MI, Mochulsky AV, Shechter II, Trukhan ME, Ratmanova KI, Rebentish BA, Kaluzhsky VE, Debabov VG: TGATG vector: a new expression system for cloned foreign genes in Escherichia coli cells. Gene 1990;88:121-126.

McGinness KE, Baker TA, Sauer RT: Engineering controllable protein degradation. $\mathrm{Mol}$ Cell 2006;22:701-707.

Miksch G, Bettenworth F, Friehs K, Flaschel E: The sequence upstream of the -10 consensus sequence modulates the strength and induction time of stationary-phase promoters in Escherichia coli. Appl Microbiol Biotechnol 2005;69:312-320.

Miller JH: Experiments in Molecular Genetics. Cold Spring Harbor, Cold Spring Harbor Laboratory Press, 1972.

Minaeva NI, Gak ER, Zimenkov DV, Skorokhodova AY, Biryukova IV, Mashko SV: Dual In/ Out strategy for genes integration into bacterial chromosome: a novel approach to stepby-step construction of plasmid-less marker-less recombinant $E$. coli strains with predesigned genome structure. BMC Biotechnol 2008;8:63.

Mogridge J, Mah TF, Greenblatt J: A proteinRNA interaction network facilitates the template-independent cooperative assembly on RNA polymerase of a stable antitermination complex containing the lambda $\mathrm{N}$ protein. Genes Dev 1995;9:2831-2845.

Mogridge J, Mah TF, Greenblatt J: Involvement of boxA nucleotides in the formation of a stable ribonucleoprotein complex containing the bacteriophage $\lambda \mathrm{N}$ protein. J Biol Chem 1998;273:4143-4148.

Nakashima N, Tamura T: Conditional gene silencing of multiple genes with antisense RNAs and generation of a mutator strain of Escherichia coli. Nucleic Acids Res 2009;37: e103.

Nakashima N, Tamura T, Good L: Paired termini stabilize antisense RNAs and enhance conditional gene silencing in Escherichia coli. Nucl Acids Res 2006;34:e138.

- Nickels BE, Roberts CW, Sun H, Roberts JW, Hochschild A: The $\sigma^{70}$ subunit of RNA polymerase is contacted by the $\lambda \mathrm{Q}$ antiterminator during early elongation. Mol Cell 2002; 10:611-622.

Nudler E, Gottesman ME: Transcription termination and anti-termination in E. coli. Genes Cells 2002;7:755-768.

-Oberto J, Clerget M, Ditto M, Cam K, Weisberg RA: Antitermination of early transcription in phage HK022. Absence of a phage-encoded antitermination factor. J Mol Biol 1993; 229:368-381.

O'Connor CD, Timmis KN: Highly repressible expression system for cloning genes that specify potentially toxic proteins. J Bacteriol 1987;169:4457-4462.
-Ponce E, Flores N, Martinez A, Valle F, Bolivar F: Cloning of the two pyruvate kinase structural genes from Escherichia coli: the relative roles of these enzymes in pyruvate biosynthesis. J Bacteriol 1995;177:5719-5722.

Ponce E, Martinez A, Bolivar F, Valle F: Stimulation of glucose catabolism through the pentose pathway by the absence of the two pyruvate kinase isoenzymes in Escherichia coli. Biotechnol Bioengin 1998;58:292-295.

Ptashne M: A Genetic Switch. Cambridge, Blackwell Scientific Publications, 1992.

Sambrook J, Russell DW: Molecular Cloning: A Laboratory Manual, ed 3. Cold Spring Harbor, Cold Spring Harbor Laboratory Press, 2001.

- Sanger F, Coulson A, Hong G, Petersen G: Nucleotide sequence of bacteriophage lambda DNA. J Mol Biol 1982;162:729-773.

- Sauer U, Lasko DR, Fiaux J, Hochuli M, Glaser R, Szyperski T, Wuthrich K, Bailey JE: Metabolic flux ratio analysis of genetic and environmental modulations of Escherichia coli central carbon metabolism. J Bacteriol 1999; 181:6679-6688

-Shaw WV: Chloramphenicol acetyltransferase from chloramphenicol-resistant bacteria. Meth Enzymol 1975;43:737-755.

-Shearwin KE, Callen BP, Egan JB: Transcriptional interference - a crash course. Trends Genet 2005;21:339-345.

-Siddiquee KAZ, Arauzo-Bravo MJ, Shimizu K: Metabolic flux analysis of $p y k F$ gene knockout Escherichia coli based on ${ }^{13} \mathrm{C}$-labeling experiments together with measurements of enzyme activities and intracellular metabolite concentrations. Appl Microbiol Biotechnol 2004;63:407-417.

-Sneppen K, Dodd IB, Shearwin KE, Palmer AC, Schubert RA, Callen BP, Egan JB: A mathematical model for transcriptional interference by RNA polymerase traffic in Escherichia coli. J Mol Biol 2005;346:399-409.

- Squires CL, Greenblatt J, Li J, Condon C, Squires CL: Ribosomal RNA antitermination in vitro: requirement for Nus factors and one or more unidentified cellular components. Proc Natl Acad Sci USA 1993;90:970-974.

- Srivastava R, Cha HJ, Peterson MS, Bentley WE: Antisense downregulation of $\sigma^{32}$ as a transient metabolic controller in Escherichia coli: effects on yield of active organophosphorus hydrolase. Appl Environ Microbiol 2000;66: 4366-4371.

Tatarko M, Romeo T: Disruption of a global regulatory gene to enhance central carbon flux into phenylalanine biosynthesis in Escherichia coli. Curr Microbiol 2001;43:26-32.

- Tchurikov NA, Chistyakova LG, Zavilgelsky GB, Manukhov IV, Chernov BK, Golova YB: Gene-specific silencing by expression of parallel complementary RNA in Escherichia coli. J Biol Chem 2000;275:26523-26529.

-Ward DF, Murray NE: Convergent transcription in bacteriophage $\lambda$ : interference with gene expression. J Mol Biol 1979;133:249-266. 